\title{
Using optimization to solve the dilemma of a municipal solid waste landfill in Delaware running out of capacity faster than predicted
}

\author{
By: Frank Gronwald, North Carolina A\&T University \\ Shoou-Yuh Chang, North Carolina A\&T University
}

\section{Abstract}

Municipal landfills play a vital role in disposing of the solid waste from a community. One of the biggest challenges landfill management face is when the available storage space is being reduced faster than the rate that was planned for. This shortening of the landfill lifecycle impacted the city of Wilmington, Delaware when it was found that their landfill had lost 11 years of its projected lifespan and would reach fully capacity within the next decade. In order to remedy the situation six alternative solutions were devised, with each having different costs (capital, operating, and transport) and varying lengths of landfill extension. This research used the principle of optimization via a LINDO program to determine which solution would achieve the longest landfill extension for the minimum total cost. Other constraints placed on the program include reducing the waste being sent to the landfill and to achieve a minimum of 25 additional years for the landfill. The calculated solution produced a cost reduction of $\$ 232.64$ million dollars and 3.2 additional years of operation from the option that was eventually chosen by the landfill authority.

Keywords: Optimization, LINDO, landfill, Delaware, recycling, municipal solid waste (MSW)

\section{Introduction}

Municipal solid waste is a term generally applied to waste emanating from mostly households with a smaller portion coming from local businesses. It is collected by the town or city and then must be 
disposed of. The most common method is burying the waste in a landfill. Landfills can either be publicly or privately owned. Generally, the waste is confined to a small area called a cell, compacted to decrease its volume, and covered with dirt at the end of the day. Some of the issues that the landfill must control include vermin, methane gas, and pollution of the groundwater or aquifer by leakage. One of the major problems occurs when the landfill runs out of available space faster than anticipated.

Delaware citizens generate about 1200 pounds of residential solid waste per person per year. About 170 pounds of this residential solid waste consists of recyclables and are recoverable. The remaining 1030 pounds must be sent to a landfill. In New Castle County alone 525,000 tons of waste are generated by 190,000 households on an annual basis. Figure 1 shows the projections for the rate of growth for solid waste accumulation. Delaware has three counties and each has its own municipal solid waste landfill controlled by Delaware Solid Waste Authority.

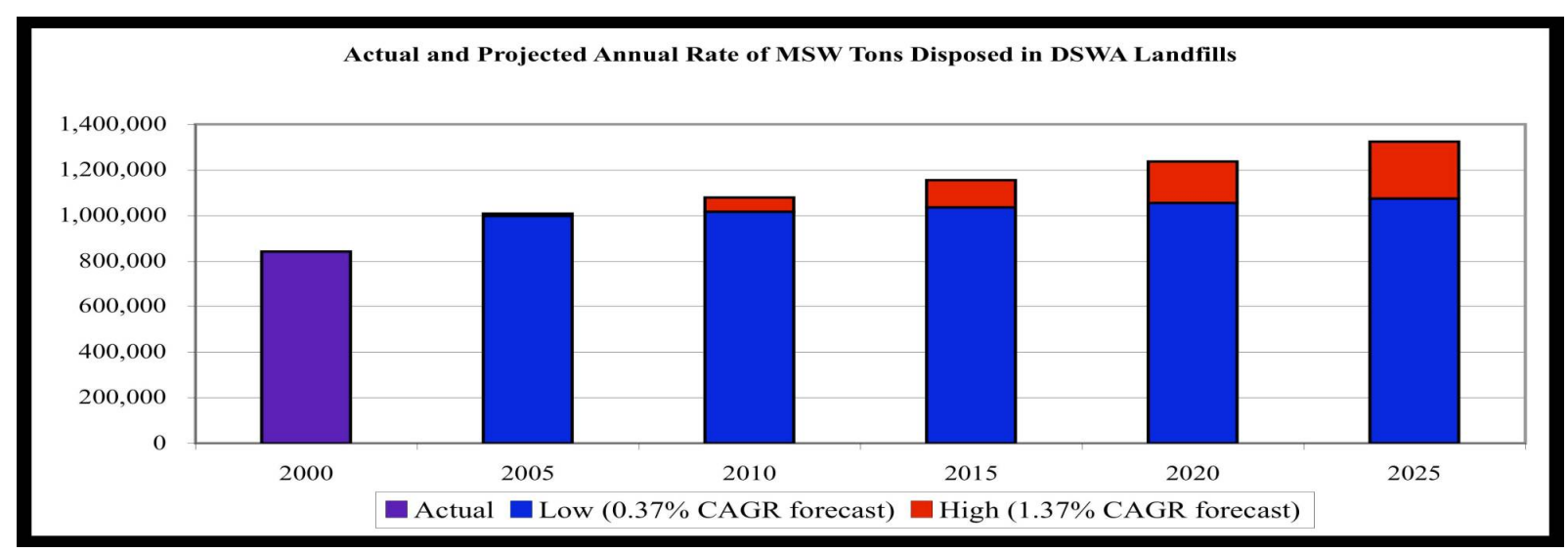

Figure 1. Projected growth for municipal solid waste disposal at Delaware landfills

A full capacity situation then occurred in 1995 at the Cherry Island Landfill, located in Wilmington, Delaware. The issue they faced was being at capacity years ahead of schedule. Cherry Island was first used as a landfill in 1958 when the DuPont Corporation purchased it from the American Dredge Company and began to dispose of the solid waste products from its Titanium Dioxide plant. 
After DuPont created and optimized the Iron Rich process, the site was no longer necessary and was closed then given to the state of Delaware (DNREC, 2004). The Cherry Island Landfill consists of 235 acres which are situated on a 513 acre site. The other portion of the site belongs to the US Army Corps of Engineers who use it to store sludge deposits from their river dredging operation. At some point in the distant future the Cherry Island Landfill will likely be transferred to private ownership and may eventually receive permission to expand their operations into sections the Army Corps of Engineers is not using. Today Cherry Island is no longer considered an ideal site for a landfill as it is bounded by two rivers: the Christiana to the south and the Delaware to the East. Expanding outward in the other directions would also not be possible due to the city wastewater treatment plant on the north boundary and an interstate highway adjacent to the western boundary (Byle, 1999). Figure 2 gives an aerial view of the city of Wilmington and its landfills. 


\section{Landfill Location Map}

Northern New Castle County

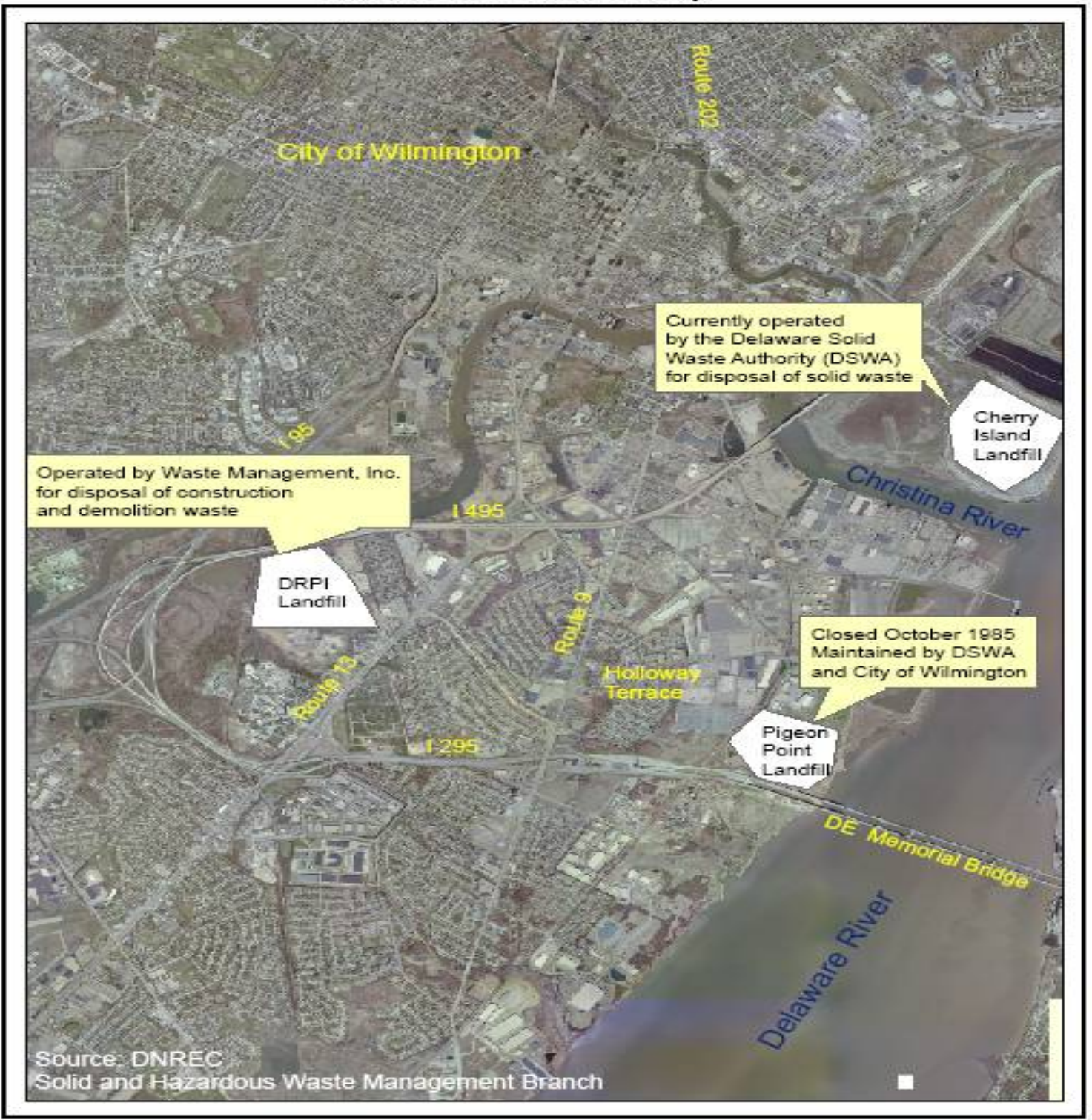

Figure 2. Map of Wilmington, DE Landfill Sites

Cherry Island was reopened in 1985 when the Pigeon Point Landfill reached capacity and was closed. Cherry Island was originally designed to have a lifespan lasting until 2017. However, there were several factors that caused the landfill to use a lot more capacity faster than anticipated. One of the 
biggest reasons for this was the population surge. Citizens of Delaware were also wasting a lot more that they used to in prior generations.

Today, the average Delawarean generates around $1200 \mathrm{lbs}$ of residential solid waste per person per year (Delaware Solid Waste Authority, 2006). New Castle Country produces 525,000 tons of waste from 190,000 households. In the late 90 's it was determined that the landfill would reach full capacity by 2006. This created a real problem for the Delaware Solid Waste Authority as there was no contingency plan in place. The first steps that they undertook were to measures to extend the landfill's life a few extra years while coming up with a more permanent solution. Drop-off recycling centers were opened at several locations around the state and within a few years $130 \mathrm{lbs}$ per person per year were being recycled and diverted away from the landfill. Some solid waste was used to investigate their compatibility and use in microbial fuel cells in hopes of discovering another possible alternative fuel source (Barbato and Gronwald, 2018). Yard waste was no longer accepted in the landfill, private companies were recruited to turn it into mulch. Old tires also were no longer allowed (Chang and Gronwald, 2016). These changes extended the expected life of the landfill a few years until 2010 (Delaware Solid Waste Authority, 2005). The Delaware Solid Waste Authority in conjunction with the Department of Natural Resources and Environmental Control (DERNEC) and the governor created a Solid Waste Management Technical Working Group to discover and evaluate long-term solid waste management solutions. Six unique proposals were given serious consideration.

\section{Proposal \#1 Build a Material Recovery Facility (MRF)}

DSWA would build and manage a Materials Recovery Facility (MRF) at Pigeon Point for sorting, processing and marketing recyclables which are collected statewide. There would be no tipping fee at the MRF. Using a $65 \%$ capture rate and estimating current market values, revenues from recyclables 
would be expected to be approximately $\$ 2.9$ million, per year. This choice would require an initial capital cost of $\$ 8.2$ million along with an annual cost of $\$ 7$ million dollars. The facility would run a deficit of about $\$ 4.1$ million. The MRF would recycle 87,400 tons per year and landfill 437,600 tons per year. For every six years of MRF operation, the landfill would gain one year. For a 25 year lifespan it would add about 4 years to the landfill's life ( DNREC, 2006).

\section{Proposal \#2 Out of State Waste to Energy: “Ash for Trash”}

This proposal would send out 368,000 tons per year to a Waste to Energy facility in Chester, PA. 184,000 tons would be brought back to the landfill as ash. The total amount that would be landfilled is 341,000 tons per year. The proposal would extend the Cherry Island Landfill an extra six years. There are no capital costs since no facility would be built but there are transportation costs of $\$ 12$ per ton (DNREC, 2006).

\section{Proposal \#3 Out of State Landfill}

This proposal would send 368,000 tons per year to an out of state landfill either in PA or VA. There would be no capital costs and transportation costs would be about $\$ 40$ per ton. 157,000 tons per year would still be added to the Cherry Island Landfill which would have its life extended 19 years.

\section{Proposal \#4 Build a New Landfill Site}

One possible option is for DSWA is to open a new landfill in New Castle County. Under local law DSWA is exempt from local zoning restrictions, but still must meet the landfill siting requirements under DNREC's Solid Waste Regulations. DSWA has not been able to identify a suitable site of at least 500 
acres in New Castle County. Even if DSWA were able to identify a suitable location in New Castle County and determine that it meets all of DNREC's siting requirements (e.g., floodplain, wetlands, public water supply), it would still have to face an inevitably tough public hearing process. It was estimated that under a best-case scenario, the time to complete design work, permit preparation, regulatory review, site preparation and construction would probably require ten years before a new landfill would be available. Building a new landfill would have a capital cost of $\$ 109$ million plus the cost of property needed and it would have an operating cost of $\$ 31$ million per year. The new landfill could be expected to operate for 27 to 30 years (DSWA, 2004).

\section{Proposal \#5 Transfer the Waste to the Sandtown Landfill in the Adjacent County}

This proposal considers transporting the solid waste collected in New Castle County to either Pigeon Point Transfer Station or Pine Tree Corners Transfer Station. At the transfer station, the waste would be condensed and placed into larger trailer trucks and driven to the Sandtown Landfill which lies 10 miles southwest of Dover. Sandtown Landfill has capacity to serve Kent County for more than 62 years, based on current rates. If the approximately 2,046 tons per day that is currently disposed at Cherry Island Landfill were transferred to Sandtown, it would shorten that landfill's remaining available life to less than 17 years. However, there is a greater probability of obtaining a new landfill in this county due to the higher availability of land. For this proposal there is a capital cost of $\$ 36$ million for the transfer station and transportation costs of $\$ 35$ per ton (DSWA, 2004).

\section{Proposal \#6 Cherry Island Landfill Vertical Expansion}

This proposal would raise the height of the landfill from $172 \mathrm{ft}$ to $288 \mathrm{ft}$. It has a capital cost of $\$ 66$ million dollars and operational costs of $\$ 24$ million per year. It would extend the landfill life more than 25 years. Figure 3 shows a graphical representation of how the expansion would look. In the short 
term, this may be the most convenient course to take; however, once expansion plans are underway it is difficult for decision makers to reverse course (DSWA, 2009). Some of the short-term options that offer significant opportunities for waste disposal or landfill avoidance such as sending the waste downstate or out of state to another landfill or WTE facility may not be available the next time the landfill runs out of capacity. Table 1 shows a summary of costs for all 6 Proposals. The objective of this research is to determine which of these proposals would be the most optimal for the reduction of waste going to the landfill.

\section{DSWA's Cherry Island Landfill Expansion Project}

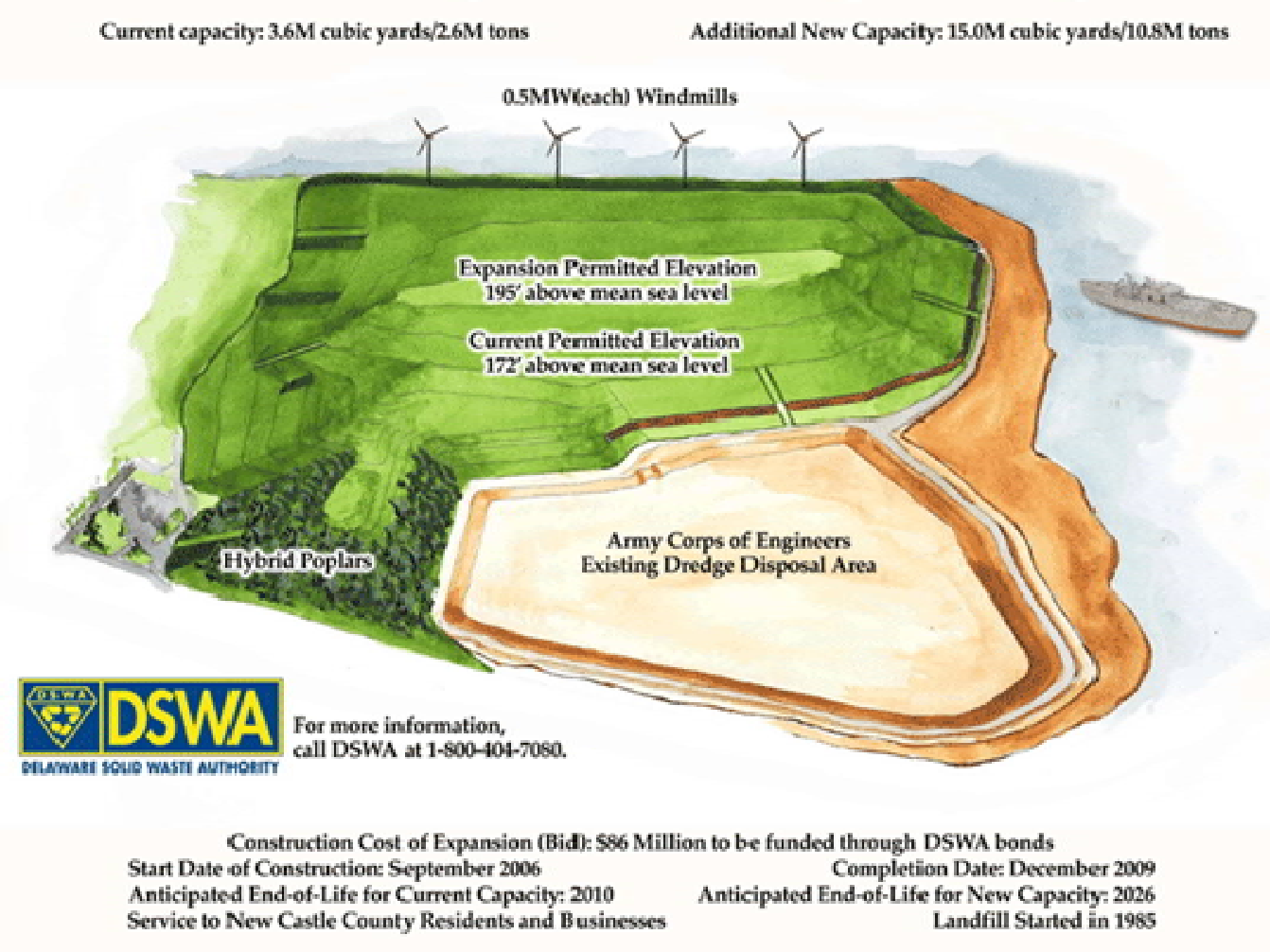

Figure 3. Graphical representation of proposed Cherry Island expansion 
Table 1. Summary of Proposal Cost, and Tons Saved and Sent to Landfill

\begin{tabular}{|l|l|l|l|l|l|l|}
\hline Proposal & Cap Cost & Operating & Trans Cost & Saved from & Sent to LF & LF Life Saved \\
& & Lost & & & \\
\hline$\#$ & (Mil $\$ / \mathrm{yr})$ & (Mil $\$ / \mathrm{yr})$ & $(\$ /$ ton) & (Tons/yr) & (Tons/yr) & (yrs) \\
\hline 1 & 8.2 & 7 & 0 & 87,400 & 437,600 & 4 \\
\hline 2 & 0 & 0 & 12 & 184,000 & 341,000 & 6 \\
\hline 3 & 0 & 0 & 40 & 368,000 & 157,000 & 19 \\
\hline 5 & 109 & 31 & 0 & 0 & 550,000 & 25 \\
\hline 6 & 36 & 0 & 35 & 0 & 550,000 & 45 \\
\hline
\end{tabular}

\section{Methodology}

The determination of the most cost effective solution is achieved through the process of optimization. The objective is to pick the proposal that has both a low cost of implementation and the ability to save a high amount of years from the landfill lifespan. The equation used for calculating the optimal solution is given in Equation 1:

$8.2 * \mathrm{Y} 1+4.1 * \mathrm{t} 1+4.14 * 6 \mathrm{t} 2+14.72 * \mathrm{t} 3+109 * \mathrm{Y} 4+31 * \mathrm{t} 4+36 * \mathrm{Y} 5+18.375 * \mathrm{t} 5+66 * \mathrm{Y} 6+5 * \mathrm{t} 6$

where $\mathrm{Y} 1, \mathrm{Y} 4, \mathrm{Y} 5$, and $\mathrm{Y} 6$ are decision variables based on capital costs and whether that facility is going to be built and $\mathrm{t} 1, \mathrm{t} 2, \mathrm{t} 3, \mathrm{t} 4, \mathrm{t} 5, \mathrm{t} 6$ are the time in years that the proposal will be implemented.

A LINDO program was written to minimize equation 1 and that is shown in Appendix A. 


\section{Results and Discussion}

The results show that the minimum cost would be $\$ 186$ Million. The optimum solution is to do proposal 2 "Ash for Trash" for six years and then expand the landfill vertically as in Proposal 6. This combination would also extend the life of the landfill by at least six extra years. The Solid Waste Management Technical Working Group decided to use a different method to determine the best proposal. They chose to evaluate each proposal based on the Reliability Method. They gave each option a weighted score based on different criteria that they felt were important. The criteria that were used include readiness and reliability, inputs and pre-processing, health and public safety which was the highest weighted criteria, energy and mass balance, economics, and legal and policy issues (DNREC, 2006). Their choice was to just expand the landfill height. This was due to already having the infrastructure in place, having less environmental impact than building a new site or hauling truckloads of trash for extra miles, and it provided the longest lasting solution until 2037 (Vidanaarachchi et al, 2006). However in ignoring the second proposal they lose out on a 38.74 million a year from the operational costs savings as well as the 3.2 extra years that the landfill would have gained in extra life before it reached capacity.

Some critics of the process feel that the numbers were biased towards the vertical expansion. The MRF option's cost was over estimated by several million dollars and when run with the proper number the optimum solution will include it and add at least four more years to the life of the landfill.

\section{References}

Barbato, R. and F. Gronwald. 2018. A Study of soil based microbial fuel cells. International Journal of Scientific Research and Engineering Development. 1:2. 60-129. 
Byle, M.J., Alexander, M.L., Vasuki, R., and J.A. Langer. 1999. Instrumentation of Dredge Spoil for Landfill Construction. American Society for Testing and Materials.

Chang, S.Y. and F. Gronwald. 2016. A Multi-criteria Evaluation of the Methods for Recycling Scrap Tires. Journal of Solid Waste Technology and Management. 42:2. 145-156.

Department of Natural Resources and Environmental Control (DERNEC). 2004. Proposed Plan of Remedial Action. Dec 14, 2004.

Department of Natural Resources and Environmental Control (DERNEC). 2007. Municipal Solid Waste and Landfill Capacity in Delaware. 2007

Delaware Solid Waste Authority. 2005 Annual Report. March, 2005

Delaware Solid Waste Authority. 2009 Annual Report. November 20, 2009.

Delaware Solid Waste Authority. Cherry Island Landfill. 2008. http:// www.dswa.com/facilities_nswmc.asp

Delaware Solid Waste Authority. 2006. Cherry Island Landfill Expansion Project. Cherry Island Landfill Public Workshop. July 11, 2006

Division of Air and Waste Management. Solid Waste Facilities. 2010.

http://www.awm.delaware.gov/SHWMB/Pages/SolidWasteFacilities.aspx.

Dooley, F.J., Bangsund, D., and F.L. Leistritz. 1993. Estimating Optimal Landfill Sizes and Locations in North Dakota. Department of Agricultural Economics, North Dakota State University.

Durham, G.N. and W.A. Marr. 2002. The Instrumentation of Soil and Rock. ASTM STP 1358. 175-190 
Noles, T. 2009. Cherry Island Landfill: Pile it Higher and Deeper. www.tommywonk.com. August 24, 2009

Solid Waste Management Technical Working Group. 2006. Solid Waste Management Alternatives for Delaware. May 15, 2006.

State of Delaware Department of Natural Resources \& Environmental Control Division of Air and Waste Management, Permit Renewal, DSWA Northern Solid Waste Manageemnt Center-2, January 6, 2006

Vidanaarachchi, C.K., Yuen, S.T., and S. Pilapitiya. 2009. Optimization Tool to Maximize Use of Resources for Environmental Improvements to Waste Disposal Sites. Practice Periodical of Hazardous, Toxic, and Waste Management.

Zekkos, A.M., Bray, J., Kavazanjian, E.J., Matasovic, N., Rathje, E., Riemer, M., and K. Stokoe. 2006. Unit Weight of Municipal Solid Waste. Journal of Geotechnical and Geoenvironmental Engineering. October 2006. 1250-1261. http://www.scdhec.gov/environment/lwm/recycle/pubs/msw_landfills.pdf

\section{Appendix A}

LINDO Optimization Program

A linear optimization model has been developed to pick out the best course of action. The optimization equation developed was:

MIN 8.2Y1+4.1t1+4.146t2+14.72t3+109Y4+31t4+36Y5+18.375t5+66Y6+5t6 
Where $\mathrm{Y} 1, \mathrm{Y} 4, \mathrm{Y} 5$, and $\mathrm{Y} 6$ are decision variables based on capital costs and whether that facility is going to be built. The variables $\mathrm{t} 1, \mathrm{t} 2, \mathrm{t} 3, \mathrm{t} 4, \mathrm{t} 5, \mathrm{t} 6$ are the time in years that the proposal will be implemented.

The Constraints that were used are listed below:

\section{SUBJECT TO}

20000Y1-t1 $>=0$

20000Y4-t4>=0

$20000 Y 5-\mathrm{t} 5>=0$

$20000 Y 6-t 6>=0$

$\mathrm{t} 1<=4$

$\mathrm{t} 2<=6$

$\mathrm{t} 3<=19$

$\mathrm{t} 4<=25$

$\mathrm{t} 5<=17$

t6< $=25$

$\mathrm{t} 1+\mathrm{t} 2+\mathrm{t} 3+\mathrm{t} 4+\mathrm{t} 5+\mathrm{t} 6>25$

$.437 \mathrm{t} 1-\mathrm{m} 1=0$

$.341 \mathrm{t} 2-\mathrm{m} 2=0$

$.157 \mathrm{t} 3-\mathrm{m} 3=0$

$.550 t 6-m 6=0$

$m 6-m 3-m 2-m 1=0$

end

int $Y 1$ 
int $Y 4$

int Y5

int $\mathrm{Y} 6$

Where $\mathrm{Y} 1, \mathrm{Y} 4, \mathrm{Y} 5$, and $\mathrm{Y} 6$ are decision variables based on the capital costs

The variables $\mathrm{t} 1, \mathrm{t} 2, \mathrm{t} 3, \mathrm{t} 4, \mathrm{t} 5$, and $\mathrm{t} 6$ are the time in years that the proposal will be implemented.

And $m 1, m 2, m 3$, and $m 6$ are the values of waste that get sent to the landfill.

\section{Appendix B}

Results from LINDO optimization program

The results obtained from running LINDO are shown below:

OBJECTIVE FUNCTION VALUE

1) $\quad 185.8760$

$\begin{array}{crc}\text { VARIABLE } & \text { VALUE } & \text { REDUCED COST } \\ \text { Y1 } & 0.000000 & -17991.800781 \\ \text { Y4 } & 0.000000 & 109.000000 \\ \text { Y5 } & 0.000000 & 36.000000 \\ \text { Y6 } & 1.000000 & 66.000000 \\ \text { T1 } & 0.000000 & 0.000000 \\ \text { T2 } & 6.000000 & 0.000000 \\ \text { T3 } & 0.000000 & 9.720000 \\ \text { T4 } & 0.000000 & 26.000000 \\ \text { T5 } & 0.000000 & 13.375000\end{array}$




$\begin{array}{lrl}\text { T6 } & 19.000000 & 0.000000 \\ \text { M1 } & 0.000000 & 0.000000 \\ \text { M2 } & 2.046000 & 0.000000 \\ \text { M3 } & 0.000000 & 61.910828 \\ \text { M6 } & 10.450000 & 0.000000\end{array}$

ROW SLACK OR SURPLUS DUAL PRICES

2) $\quad 0.000000 \quad-0.900000$

3) $\quad 0.000000 \quad 0.000000$

4) $\quad 0.000000 \quad 0.000000$

5) $19981.000000 \quad 0.000000$

6) $\quad 4.000000 \quad 0.000000$

7) $\quad 0.000000 \quad 0.854000$

8) $\quad 19.000000 \quad 0.000000$

9) $\quad 25.000000 \quad 0.000000$

10) $\quad 17.000000 \quad 0.000000$

11) $6.000000 \quad 0.000000$

12) $0.000000 \quad-5.000000$

NO. ITERATIONS $=22$

BRANCHES $=1$ DETERM $=1.000 \mathrm{E} \quad 0$ 